\title{
STUDI FENOMENOLOGIS DINAMIKA PSIKOLOGIS SANTRI PEMBELAJAR
}

\author{
Oleh: \\ Saifullah \& Abd Mughni \\ Fakultas Dakwah IAI Ibrahimy Situbondo \\ saivul.07@gmail.com \& abd.mughni@gmail.com
}

\begin{abstract}
:
This study was qualitative-phenomenological approach aimed to identifying and understanding more deeply about the self-regulated learning of islamic boarding school students. The subjects of this study consist of 3 islamic students were lived in boarding scool. The results indicated that the three subjects conducted self-regulation in learning through regulating the metacognition, motivation, behavior, help seeking in order to achieve certain learning objectives. Self-regulated learning performed by the subjects was influenced by specific precipitating situations and the social support that given to them.
\end{abstract}

Keywords: Self-Regulated Learning, Islamic Students, Motivation, Help Seeking

\section{A. Pendahuluan}

Masa remaja merupakan masa peralihan dari masa anak-anak menuju usia dewasa. Pada masa peralihan ini biasanya terjadi percepatan pertumbuhan dalam segi fisik yang ditandai dengan perubahan bentuk badan, sikap, cara berpikir, dan bertindak. Masa remaja merupakan masa perubahan dan transisi dihampir setiap aspek kehidupan. ${ }^{1}$ Schunk mengemukakan bahwa masalah yang dihadapi remaja adalah masalah penyesuaian diri (dengan keluarga, sekolah, masyarakat), kontrol emosi, beragama, kesehatan, ekonomi, pendidikan, serta mengisi waktu luang. ${ }^{2}$ Remaja dapat berfikir dalam kerangka apa yang mungkin terjadi, mereka dapat membayangkan kemungkinan dan dapat menyusun hipotesis. ${ }^{3}$

1Santrock, Jhon. W. Life-span development (Edisi Kelima). Alih bahasa oleh Juda Damanik dan Achmad Chusairi. Jakkarta: Penerbit Erlangga. 2008, hlm 8-13. Lihat Juga Papalia, Diane. E., Old, Salle. W, \& Feldman, Ruth. D. Human Development.Terjemahan edisi ke-9: Anwar, K.A. Jakarta: Pernada Media Grup. 2008, hlm. 542-544.

${ }^{2}$ Schunk, Dale. H. Learning theories: an educational perspective ( $5^{\text {th }} \mathrm{ed}$.). New Jersey: Pearson Education, Inc. 2008, hlm. 329-330.

${ }^{3}$ Slavin, Robert. E. Educational psychology: Theory and practice ( $9^{\text {the }}$ d.). New Jersey:

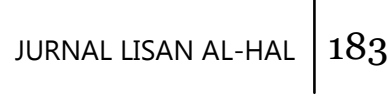


Remaja ingin eksistensinya mendapat pengakuan dalam lingkungan sosial, berusaha untuk mengekspresikan kreativitas dan produktifitasnya. Banyaknya permasalahan dan krisis yang terjadi pada masa remaja menjadikan banyak ahli psikologi perkembangan menyebutnya sebagai masa krisis karena terjadi perubahan yang drastis dengan kondisi psikis yang belum matang (mature). Menurut Erikson, periode ini dinilai sangat penting, karena seluruh masa depan individu sangat tergantung pada penyelesaian krisis pada masa remaja. ${ }^{4}$

Remaja dituntut untuk mampu mengatur diri guna mencapai kesuksesan di masa mendatang. Pengaturan diri menjadi salah satu kemampuan penting yang harus dikembangkan oleh setiap individu untuk dapat menyelesaikan tugas perkembangannya. Pengaturan diri sebaikbaiknya terhadap intelektulilitas, tenaga, waktu, dan semua sumber daya dalam belajarnya. Kemampuan intelektual remaja yang telah dirangsang sejak awal melalui berbagai macam sarana dan prasarana yang disiapkan di rumah maupun di luar rumah seperti media sosial, televisi, radio, surat kabar, dan film. Remaja diharapkan mampu menghadapi hambatan atau masalah yang biasanya muncul dalam bentuk perilaku bermasalah yang berdampak pada terhambatnya proses sosialisasi dengan teman sebaya, guru, dan masyarakat atau mengikuti berbagai aktivitas sosial untuk membentuk pengalamannya. Dalam menghadapi masalah-masalah tersebut, ada remaja yang mampu memecahkan masalahnya sendiri, namun ada pula yang mengalami kesulitan sehingga membutuhkan keterampilan, pengetahuan, serta pengalaman yang dapat diperoleh dari dan orang lain 5 .

Remaja santri (untuk selanjutnya disebut santri) yang tinggal di pondok pesantren "X" di Situbondo Jawa Timur harus mengurus sendiri keperluan sehari-harinya. Santri wajib mengikuti setiap kegiatan yang telah ditetapkan oleh pemangku kebijakan pesantren. Rutinitas kegiatan di pondok pesantren ini sangat padat dan terstruktur hingga menuntut santri untuk kerja keras mengikuti kegiatan kepesantrenan. Kegiatan yang padat dan tersruktur dianggap sebagai tantangan dan hambatan bagi

Pearson. 2009, hlm. 40-41.

4Papalia, Diane. E., Old, Salle. W, \& Feldman, Ruth. D. Human Development.Terjemahan edisi ke-9: Anwar, K.A. Jakarta: Pernada Media Grup. 2008, hlm. $542-544$.

${ }^{5}$ Santrock, Jhon. W. Life-span development (Edisi Kelima). Alih bahasa oleh Juda Damanik dan Achmad Chusairi. Jakkarta: Penerbit Erlangga. 2008, hlm 19-32.

$184 \mid$ JURNAL LISAN AL-HAL 
mereka untuk menyesuaikan diri dengan tuntutan kegiatan tersebut. Kegiatan dimulai dari shalat shubuh berjamaah dan dilanjutkan dengan mengaji al-qur'an di asrama, kemudian rangkaian kegiatan akan berahir hingga mereka menjelang tidur kembali di waktu malam. Aktivitas belajar di pondok pesantren tempat penelitian ini dilakukan memberikan banyak tantangan. Tugas-tugas belajar dari madrasah dan sekolah menuntut santri untuk dapat menyelesaikannya sesegera mungkin. Disisi lain kegiatan kepesantrenan juga tidak bisa diabaikan begitu saja. Banyaknya tugas dan tingginya hambatan yang dihadapi sumber data memungkinkan mereka meninggalkan tugas-tugas yang menuntutnya segera diselesaikan. Dampak dari banyaknya kegiatan tersebut menjadikan santri mengalami kesulitan dalam menentukan prioritas antara belajar atau mengikuti kegiatan kepesantrenan. Problem ini menguras emosi santri sehingga mereka merasa gagal dalam memenuhi tuntutan yang harus mereka prioritaskan.

Padatnya kegiatan ini kadangkala membuat santri merasa frustrasi, disisi lain mereka sadar bahwa yang mereka hadapi merupakan sebuah proses untuk memperoleh ilmu pengetahuan dan membentuk sikap disiplin mereka baik dalam belajar maupun dalam kehidupan sehari-hari. Disiplin dan tanggung jawab yang tinggi dapat memacu mereka melakukan kegiatan kepesantrenan atau belajar. Disiplin, kerja keras, dan tanggungjawab merupakan perilaku keterikatan terhadap tugas-tugas yang diterima oleh individu. Santri dituntut untuk otonom dalam kehidupan sehari-hari, bertanggungjawab terhadap aktivitas belajarnya, dan memiliki pengetahuan dan tujuan strategis serta memiliki kemandirian untuk merencanakan dan mengerahkan kemampuannya secara efektif dalam belajar. Mereka berpacu melakukan kegiatan belajar karena tidak ingin menyia-nyiakan kesempatan selama berada di dalam pesantren. Gambaran setting sosial di atas mempengaruhi regulasi diri remaja santri dalam belajar. Pada kondisi seperti yang telah dipaparkan sebelumnya, semua santri ingin memenuhi segala tuntutan yang dihadapinya.

Zimmerman dan Martinez-Pons berpendapat bahwa salah satu syarat kesuksesan pembelajar adalah belajar berdasar regulasi diri (selfregulated learning). ${ }^{6}$ Selanjutnya dikatakan bahwa belajar berdasar

${ }^{6}$ Zimmerman, B.J. \& Martinez-Pons, M. Pursuing academic self-regulation: a 20 years methodological quest. Dalam Jessie-Ee, Chang,A,.\& Tan, C.S. (Eds), Thinking about thinking : What educators need to know. (hh.3-30) Singapura: McGraw-Hill Education (asia). 2004. 
regulasi diri berakar dari teori kognitif sosial triadik Bandura dengan melibatkan tiga determinan yaitu proses personal pembelajar, lingkungan, dan perilaku. Bandura menyatakan, belajar berdasar regulasi diri adalah aktivitas belajar yang dilakukan pelajar secara aktif, baik secara motivasional, metakognitif, maupun dalam perilaku belajarnya. ${ }^{7}$ Penggunaan strategi belajar berdasar regulasi diri tidak hanya bergantung pada pengetahuan mereka mengenai strategi belajar, tapi juga berdasar pada proses pengambilan keputusan metakognitif dan hasil kinerja pembelajar. Berdasar pada formulasi triadik ini, maka belajar berdasar regulasi diri bukanlah suatu keadaan fungsional yang mutlak, tapi lebih bervariasi, bergantung pada konteks tugas-tugas akademik, usaha individu untuk meregulasi diri, dan hasil dari kinerja perilaku. Pembelajar yang terregulasi dirinya diasumsikan mengerti pengaruh lingkungan atas perilaku mereka, baik perilaku yang nampak maupun perilaku yang tidak tampak selama akuisisi pengetahuan, dan mereka juga mengetahui bagaimana meningkatkan lingkungan menjadi kondusif melalui penggunaan berbagai macam strategi belajar. ${ }^{8}$ Belajar berdasar regulasi diri menuntut pembelajar dapat meregulasi kognisi dan motivasi belajarnya. Regulasi kognisi adalah kemampuan pembelajar memilih dan menggunakan berbagai macam strategi kognitif untuk mengingat, mempelajari, menalar, memecahkan problem, dan berfikir. Regulasi motivasi meliputi fikiran dan tindakan atau perilaku sebagai landasan bagi pembelajar bertindak untuk mempengaruhi pilihannya, usahanya, atau persistensinya terhadap tugas-tugas akademik.

Pada level regulasi diri yang bersifat umum, analisis tugas atau perencanaan adalah proses pengambilan keputusan untuk memilih dan mengubah strategi regulasi diri secara umum. Perencanaan dan sistem regulasi diri pada aspek kognisi seseorang sangat penting dan merupakan mekanisme internal yang dapat berimplikasi kuat terhadap perilaku seseorang. Perencanaan diasumsikan terjadi atas dasar sifat tugas dan lingkungan, pengetahuan (deklaratif dan prosedural), tujuan, efikasi diri, keadaan afektif, dan hasil dari kontrol perilaku. ${ }^{9}$ Sedangkan pada level

\footnotetext{
${ }^{7}$ Bandura, A. Soscial Foundations of Thought and Actions: A Social Cognitive Theory. New Jersey: Prentice Hall. Inc. 1986.

${ }^{8}$ Ablard, K.E. \& Lipschultz, R.E. Self regulated learning in high achieving students: Relation to advanced reasoning, achievement goals, and gender. Journal of Educational Psychology, 90, 94-101. 1998.

${ }^{9}$ Zimmerman, B. J. Self-regulated learning and academic achievement: An overview. Educational Psychologist, 25, 3-17, 1990.
}

$186 \mid$ JURNAL LISAN AL-HAL 
regulasi diri yang sifatnya khusus, proses kontrol perilaku nampak dalam aktivitas pembimbingan dan pengarahan atensi, pelaksanaan aktivitas, persistensi, dan pemantauan terhadap respon. Selanjutnya dikatakan bahwa melalui belajar berdasar regulasi diri pembelajar dapat membuat suatu strategi yang mengacu pada kemampuan individu untuk mengatur dirinya dalam proses belajar, dengan mengikut sertakan kemampuan metakognisi, motivasi, dan perilaku aktif.

Belajar berdasar regulasi diri sangat menekankan pada otonomi dan tanggungjawab pembelajar terhadap aktivitas belajarnya sendiri yang meliputi kesadaran dan evaluasi terhadap proses berpikir, penggunaan strategi yang selektif dan tepat, serta motivasi diri secara terus-menerus. ${ }^{10}$ Pembelajar yang meregulasi diri umumnya dicirikan sebagai pembelajar yang aktif, mampu mengelola pengalaman belajarnya secara efisien, menggunakan strategi kognitif dan metakognitif yang siap dipakai bila diperlukan untuk melaksanakan tugas-tugas belajar. Pembelajar sebagai individu berupaya untuk mengatur diri, menyeleksi dan memanfaatkan lingkungan maupun menciptakan lingkungan yang mendukung aktivitas belajar. Dengan demikian, pembelajar memiliki otonomi dalam dirinya untuk memilih, menyusun dan menciptakan lingkungan sosial dan fisik seimbang dalam mencapai belajar yang optimal.

Kemampuan metakognisi mengacu pada seberapa besar pengetahuan individu mengenai dirinya dalam merencanakan, mengorganisasi atau mengatur, menginstruksikan diri, memonitor, dan mengevaluasi diri dalam belajar. Komponen regulasi metakognitif meliputi perencanaan, pemantauan, dan evaluasi hasil belajar; sedangkan komponen perilaku meliputi strategi belajar kognitif dan strategi pengelolaan lingkungan dan sumber daya. Motivasi merupakan pendorong (drive) yang ada pada diri individu yang mencakup persepsi terhadap efikasi diri, kompetensi, dan otonomi yang dimiliki dalam aktivitas belajar. ${ }^{11}$ Komponen motivasi meliputi nilai intrinsik dan ekstrinsik, nilai tugas, efikasi diri, dan keyakinan mampu melakukan kontrol. Dengan belajar berdasar regulasi diri, secara metakognitif pembelajar aktif merencanakan, mengorganisasi, mengatur diri, memantau diri, dan mengevaluasi diri pada berbagai tahap dalam proses belajar. Secara motivasional pembelajar yang meregulasi diri dalam belajar menunjukkan

${ }^{10}$ Steffens, K. Self-regulated learning in technology enhanced learning environments: Lessons of a european peer. European Journal of Education, 41 (3/4), 353-379. 2006.

${ }^{11}$ Pintrich, P. R. A motivational science perspective on the role of student motivation In learning and teaching contexts. Journal of Educational Psychology, 95(4), 66-686. 2003. 
efikasi diri yang tinggi, atribusi diri, dan memiliki minat intrinsik terhadap belajar serta menunjukkan usaha dan persistensi yang tinggi dalam belajar. Secara behavioral, pembelajar yang belajar berdasar regulasi diri akan aktif memilih, menstruktur, dan menciptakan lingkungan yang dapat mengoptimalkan belajar, mencari saran, mencari informasi, menempatkan dirinya pada situasi yang memungkinkan untuk belajar, memerintah diri sendiri, dan menghadiahi diri sendiri atas keberhasilan belajarnya.

Eggen dan Kauchak mengatakan bahwa belajar berdasar regulasi diri terjadi ketika pelajar secara sistematik mengarahkan perilaku dan kognisinya dalam mengikuti dan memperhatikan pelajaran, memproses dan mengintegrasikan pengetahuan, mengulang-ulang informasi untuk diingat, dan mengembangkan serta mempertahankan keyakinan positif (positive beliefs) akan kemampuan belajarnya dan mengantisipasi hasil dari aktivitas belajarnya. ${ }^{12}$ Pembelajar yang meregulasi dirinya mengetahui kelebihan-kelebihan dan kekurangannya dan mengetahui bagaimana cara memanfaatkannya secara produktif dan konstruktif untuk kemudian menggunakan kemampuannya mengorganisir dan mengimplementasikan tindakan-tindakan yang diperlukan untuk dapat menyelesaikan tugas secara memuaskan.

Reviu terhadap beberapa penelitian yang dilakukan oleh Zimmerman menemukan bahwa pelajar yang meregulasi diri memungkinkan untuk memiliki kognisi, motivasi, dan prestasi yang lebih tinggi dibandingkan dengan pelajar yang tidak melakukan regulasi diri dalam belajarnya. ${ }^{13}$ Alsa (2007) juga menemukan bahwa pelajar yang berprestasi tinggi melakukan pengelolaan lingkungan lebih baik daripada pelajar yang berprestasi rendah, pelajar yang meregulasi diri cenderung menstruktur kembali lingkungan fisiknya agar dapat memenuhi kebutuhannya dalam belajar. ${ }^{14}$ Hasil-hasil penelitian terdahulu belum ada yang menggambarkan fenomena belajar berdasar regulasi diri pada santri sebagai pembelajar di pondok pesantren. Peneliti ingin mendapat gambaran tentang belajar berdasar regulasi diri santri dalam perspektif mereka sehingga mampu melalui kegiatan-kegiatan di pondok pesantren.

\footnotetext{
${ }^{12}$ Eggen, P., \& Kauchak, D. Educational psychology: Windows on classrooms (8thed.). New Jersey: Pearson Education, Inc. 2010, hlm. 185-187.

13Zimmerman, B. J. Academic studying and the development of personal skill: A selfregulatory perspective. Educational Psychologist, 33, 73-86. 1998.

${ }^{14}$ Alsa, A. Program Belajar, Jenis Kelamin, BelajarBerdasar Regulasi Diri dan Prestasi BelajarMatematika Pada Pembelajar SMA Negeridi Yogyakarta. Disertasi tidak diterbitkan, Yogyakarta, Pasca Sarjana UGM, 2007.
}

$188 \mid$ JURNAL LISAN AL-HAL 
Hal-hal apa saja yang membentuk belajar berdasar regulasi diri pada mereka. Inilah kemudian yang menjadi pertanyaan penelitian yang diajukan dalam penelitian ini yaitu bagaimanakah dinamika psikologis remaja santri dalam belajar di pondok pesantren "X" di Situbondo Jawa Timur?

\section{B. Hasil dan Pembahasan}

\section{Hasil Penelitian}

Penggunaan metode penelitian kualitatif-fenomenologis dalam penelitian ini sejalan dengan pernyataan Zimmerman dan Martinez-Pons menyatakan bahwa diperlukan suatu deskripsi melalui penelitian untuk melihat bagaimana suatu konteks dapat membentuk, memfasilitasi, dan membatasi belajar berdasar regulasi diri yang dialami oleh individu dalam proses belajar. 15 Temuan-temuan dalam penelitian ini direduksi menjadi deskripsi-deskripsi fenomenologis individu untuk kemudian dirangkum dalam tema-tema yang muncul dari seluruh sumber data penelitian.

\section{a. Latar Belakang Munculnya Belajar Berdasar Regulasi Diri Pada Santri}

Sumber data penelitian menyadari bahwa mereka memiliki banyak aktivitas sehingga muncul kesadaran untuk mengatur semua aktivitas yang mereka lakukan termasuk aktivitas dalam memenuhi tuntutan belajar mereka di madrasah dan sekolah. Kemampuan mereka dalam mengatur belajar dan juga motivasi diri untuk belajar membuat mereka mampu menjalani semua aktivitas yang ada di pesantren. Mereka juga menyadari bahwa banyaknya aktivitas yang harus mereka laksanakan tidak sebanding dengan kemampuan fisik dan waktu yang cukup untuk melaksanakan semua kegiatan tersebut tepat waktu. Keadaan ini, menuntut semua sumber data penelitian berusaha keras mengatur tenaga dan waktu agar dapat menjalankan aktivitas sesuai dengan aturan di pesantren.

Seluruh sumber data penelitian sebagaimana hasil wawancara menyebutkan bahwa mereka seringkali mengharapkan dukungan dari lingkungan sekitar seperti peer group, kepala asrama, bagian ubudiyah, keamanan, dan suasana belajar yang kompetitif. Bentuk dukungan tersebut diharapkan hadir ketika mereka melakukan kegiatan

15Zimmerman, B.J. \& Martinez-Pons, M. Pursuing academic self-regulation : a 20 years methodological quest. Dalam Jessie-Ee, Chang,A,.\& Tan, C.S. (Eds), Thinking about thinking : What educators need to know. (hh.3-30) Singapura: McGraw-Hill Education (Asia). 2004. 
kepesantrenan dan mengerjakan tugas-tugas belajar dari sekolah atau madrasah. Menurut mereka, dukungan-dukungan tersebut dapat membantu mempermudah penyesuaian diri mereka dalam melakukan segala aktivitas yang harus mereka kerjakan. Dengan demikian aktivitas belajar yang dilakukan dapat diarahkan pada pencapaian tujuan belajar yang optimal. Seluruh sumber data meyakini bahwa dukungan yang mereka dapatkan dari kepala asrama, teman, guru, dan lingkungan sekitar memberikan kontribusi yang besar dalam menjalani proses kehidupan sebagai santri.

\section{b. Harapan, Orientasi Tujuan, Kerja Keras, dan Hambatan Sebagai Makna Belajar Berdasar Regulasi Diri Bagi Santri}

Sumber data SH, RA, dan IIAH meyakini urgensi penetapan tujuan belajar dan motivasi belajar dapat mendorong seseorang membangun motivasi belajar dan kemungkinan mencapai tujuan lebih besar. Sebagaimana yang dituturkan oleh SH seperti berikut ini:

"....orang cari ilmu itu kan harus punya tujuan, jika ndak punya tujuan maka himmah untuk belajar tidak akan ada bahkan tidak akan jadi untuk belajar"16.

Semua sumber data mempunyai keinginan memiliki prestasi belajar yang membanggakan baik di lingkungan madrasah, sekolah, ataupun di lingkungan pesantren. Keinginan tersebut menurutnya dapat dicapai dengan kerja keras dan memamfaatkan waktu sebaik mungkin di tengah-tengah melakasanakan kewajiban pesantren. Pemanfaatan waktu senggang yang optimal merupakan suat hal yang sangat berharga bagi mereka. Target jangka pendek yang ingin mereka capai yaitu memiliki prestasi akademik di bangku madrasah dan sekolah, sementara target jangka panjangnya adalah menentukan cita-cita untuk meraih masa depan yang lebih baik. Orientasi tujuan belajar yang dilakukan santri dapat memotivasi mencapai tujuan belajar dengan strategi mengoptimalkan modalitas karakteristik yang dikembangkan untuk mengatasi hambatanhambatan yang bersumber dari internal diri individu seperti gangguan suasana hati, perasaan jenuh, dan kebosanan.

Rasa optimisme santri juga menentukan persistensi mereka dalam belajar. Padatnya kegiatan kepesantrena yang harus dijalankan oleh sumber data kadang kala membuatnya sebagai hambatan sekaligus juga sebagai tantangan yang memacu mereka menjadi remaja pekerja keras

${ }^{16}$ (W1. SH. 27-30)

$190 \mid$ JURNAL LISAN AL-HAL 
(hardiness), penuh harapan (hope) disiplin (diciplinary), patuh (obidience) terhadap orangtua, guru, dan orang yang lebih tua serta berwawasan kemasa depan. Seperti penuturan SH berikut ini:

"....tujuan kita disini emang cari ilmu, trus berusaha sebaik-baiknya eee apa

lagi ya...belajar disiplin mengikuti kegiatan dan masih banyak lagi"17.

Karakter disiplin dan bekerja keras merupakan bentuk belajar berdasar regulasi yang ditunjukkan oleh sumber data. Disiplin, kerja keras, dan penuh harapan merupakn perilaku keterikatan terhadap tugas-tugas yang diterima oleh santri sebagai pembelajar.

\section{c. Mengatur Strategi Belajar sebagai Makna Belajar Berdasar Regulasi Diri}

Beberapa strategi belajar yang dilakukan oleh sumber data $\mathrm{SH}$, RA,dan IIAH, yaitu; mengulang materi pelajaran, mengelaborasi, mengorganisasi bahan pelajaran, menghapal, meringkas, membuat skema, dan membuat catatan. Seluruh sumber data penelitian dalam belajaranya lebih menyukai metode diskusi dengan kelompok belajarnya baik itu kelompok belajar yang dibentuk sendiri di sekolah ataupun kelompok belajar yang ada di asrama. Menurut mereka metode diskusi lebih memberikan manfaat terhadap anggota kelompok, melalui diskusi mereka dapat sharing pemahaman materi pelajaran sebagaimana dituturkan oleh IIAH berikut ini:

".....untuk itu saya dan temen-temen itu sering belajar bareng / diskusi dan itu membantu saya dan temen-temen bisa lebih paham dalam belajar karena apabila saya salah pasti ada yang memperbaikinya, karena kita tidak berfikir sendiri dan juga banyak ilmu yang kita terima"18.

Belajar kelompok menurut mereka memfasilitasi dirinya dan membuat teman-temannya dapat memahami materi pelajaran secara konprehensif. Melalui diskusi ada koreksi yang dapat dilakukan secara langsung dan saling bertukar pemikiran. Sumber data $\mathrm{SH}$ dan IIAH menyatakan bahwa belajar kelompok memfasilitasi mereka untuk mendaptkan informasi atau sharing pemahaman materi. Menurut RA, ia lebih suka minta bantuan temannya untuk membantunya memberikan pemahaman terhadap materi yang sulit dipahami karena baginya minta bantuan terhadap teman lebih mudah untuk mengkomunikasikan apa yang menjadi kesulitannya dalam materi pelajaran. Upaya sumber data dalam mencari bantuan dapat dilihat dari penuturan RA seperti berikut ini:

${ }^{17}$ (W1. SH. 18-19)

18 (W1. IIAH. 46-51) 
“.....saya sering minta diajari ke temen kalo lagi gak faham....kalo temen kan enak kita bisa bilang apa yang gak kita pahami nah udah gitu saya coba ulangi lagi belajar di kamar sendirian itu kalo masih ada waktu"19.

Belajar dan memperoleh pemahaman yang komprehensif tentang suatu hal yang dipelajari merupakan impian semua pembelajar. Demikan halnya bagi santri, mereka melakukan berbagai upaya untuk memahami apa yang telah mereka pelajari seperti melakukan diskusi dengan kelompok belajarnya. Untuk mengetahui tingkat pemahaman terhadap materi yang dipelajari mereka mencatat materi yang belum atau sudah dipahaminya, apakah hasilnya sesuai dengan apa yang direncanakan sebelumnya. Checklist ini dilakukan untuk mengukur kemampuan pemahaman terhadap pelajaran yang dipelajarinya, mempermudah belajar mereka dan menyususn kembali hal-hal yang akan mereka pelajari. Hal ini sesuai dengan pernyataan RA seperti berikut ini :

"saya kan buat catatan yang belum / yang udah dikuasai dengan mengevaluasi hasil belajar kita akan tahu sampai dimana kemampuan kita dan berhasilkah rencana belajar yang sudah kita tetapkan serta tidak siasianya pelaksanaan belajar yang membutuhkan persiapan-persiapan terutama waktu, tenaga dan pikiran ${ }^{20 "}$.

Cara lain yang digunakan untuk mengevaluasi hasil belajar mereka adalah dengan membut kuis. Kuis dianggap berfungsi sebagai sarana evaluasi untuk mengetahui pemahaman remaja santri dalam belajar, dengan menggunakan kuis kelebihan dan kekurangan pembelajar akan segara diketahui dan ketika diantara kelompok tidak ada yang mampu menyelesaika kuis tersebut, maka pembuat kuis akan meberikan penjelasan sehingga anggota kelompok dapat memahami materi yang telah dikuiskan. Hal ini dilakukan untuk mengingat-ingat materi yang telah dipahaminya. Seperti yang dituturkan oleh SH, seperti berikut ini :

"Saya sering juga melakukan tanya jawab dengan teman untuk mengetes apa yang saya kuasai biar bisa dingat-ingat gitu, kalo temen-temen tidak bisa jawab baru saya jelasin"21.

Disamping checklist dan kuis, sumber data juga melakukan evaluasi belajar dengan mengevaluasi cara atau metode belajar yang digunakan serta rencana belajar yang ditetapkan sebelumnya. Hal ini penting dilakukan karena akan berdampak pada kegiatan belajar selanjutnya, jika rencana belajar tidak berjalan sesuai rencan maka perlu diperbaiki,

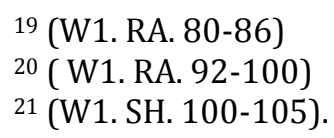


sehingga adanya perubahan rencana yang dilakukan akan didapat hasil yang optimal. Demikian juga metode belajar yang diterapakan, jika kurang berhasil mungkin bisa diganti dengan metode yang lain yang dapat meningkatkan kemampuan belajarnya. Semua ini dilakukan untuk meningkatkan prestasi belajar belajar pada jenjang berikutnya.

\section{d. Regulasi Motivasi dan Strategi Belajar Metakognitif}

Hasil temuan pada penelitian ini juga menunjukkan bahwa sumber data selalu berusaha mengatur jadwal dan menggunakan waktu belajarnya dengan baik, mereka juga menggunakan berbagai sumber belajar disamping catatan-catatan kecil yang selalu mereka bawa, menjalin komunikasi dengan teman madrasah atau sekolah, menggunakan waktu sebaik-bainya, dan mengisi waktu luang dengan berbagi pengetahuan untuk menangkap substansi materi pelajaran yang telah dipelajari.

Semua sumber data mengakui bahwa banyaknya aktivitas yang harus mereka laksanakan membuat mereka mengalami konflik yaitu kesulitan membagi waktu untuk memenuhi tuntutan belajar dengan tuntutan mengikuti kegiatan-kegiatan kepesantrenan. Konflik-konflik ini membuat sumber data melakukan perencanaan yang matang, mengorganisasi waktu dan belajar, mengatur diri (kemampuan kognitif dan belajar), memantau diri, dan mengevaluasi diri pada berbagai tahap dalam proses belajar. Hal ini sesuai dengan pernyataan RA berikut ini:

".....kita tidak hanya menetapkan satu pelajaran saja maka pelajaran yang lain akan terabaikan sehingga kita unggul dalam pelajaran yang kita tetapkan tadi sedangkan yang lainnya tidak bisa untuk dikuasai oleh sebab itu saya lebih memilih untuk mempelajari semua pelajaran dari pada hanya mempelajari satu pelajaran saja sebab antara pelajaran yang satu dengan pelajaran yang lainnya salaing mendukung"22.

Suasana lingkungan yang penuh dengan kegitan menurut mereka dapat juga memberikan dukungan dalam optimalisasi belajar, membangkitkan motivasi, memacu semangat belajar untuk meraih kesuksesan, memperkaya informasi yang didapat dari lingkungan sekitar, berkeluh kesah tentang aktivitas keseharian.

\section{Pembahasan}

Temuan dalam penelitian ini menunjukkan keberhasilan santri pembelajar banyak melakukan regulasi diri dalam belajar mendukung hasil-hasil penelitian sebelumnya yang sejalan dengan hasil penelitian ini

22 (W1. RA. 45-54). 
seperti hasil penelitian Chairani (2008), yang mengemukakan bahwa belajar berdasar regulasi diri santri penghafal Al-Qur'an di pondok pesantren di Yogyakarta sangat dipengaruhi oleh aspek-aspek tujuan, motivasional, karakteristik kepribadian, sumber dukungan, dan pemaknaan pada proses yang dijalaninya. ${ }^{23}$ Strategi ini dianggap sebagai solusi terbaik bagi mereka, dengan memanfaatkan waktu luang yang sedikit itulah, dinamika belajar mereka menjadi fokus dan optimal dalam memanfaatkan waktu yang sedikit. Tujuan belajar tidak hanya menetapakan yang akan diraih, tetapi bagaimana santri menjadi remaja santri yang feuturistik penuh dengan cita-cita yang dapat membangun semangat pembelajar berprestasi.

Temuan dalam penelitian ini menunjukkan bahwa proses belajar yang dijalankan oleh sumber data memberikan kontribusi yang bermakna terhadap belajar berdasar regulasi diri santri. Teori kognitif sosial memandang sebagian besar perilaku manusia bertujuan dan diregulasi oleh kemampuan berfikir ke depan yaitu dengan cara memotivasi diri sendiri dan mengarahkan perilakunya secara antisipatif. ${ }^{24}$ Belajar berdasar regulasi diri merupakan hasil struktur kausalitas interdependen resiprokal triadik dari aspek pribadi, perilaku, dan lingkungan. Ketiga aspek ini merupakan aspek-aspek determinan dalam belajar berdasar regulasi diri yang saling berhubungan, dimana person berusaha untuk meregulasi diri sendiri hasilnya berupa kinerja atau perilaku, dan perilaku ini berdampak pada perubahan lingkungan.

Orientasi tujuan merupakan bentuk belajar berdasar regulasi diri yang dialami oleh sumber data pada penelitian. Orientasi tujuan merupakan sasaran yang ingin dicapai oleh mereka dalam menjalankan tugas-tugas belajar. Komitmen yang kuat dalam menentukan tujuan performansi yang ingin dicapai diperkuat oleh keyakinan diri mereka bahwa mereka memiliki kemampuan untuk meraih semua tujuan belajarnya di pondok pesantren. Perspektif psikologi memandang bahwa orientasi tujuan yang ditetapkan oleh sumber data meliputi dua aspek, yaitu penguasan materi belajar dan tujuan performansi. Orientasi penguasan materi belajar merupakan upaya pembelajar fokus pada bagaimana pembelajar dapat belajar dan menguasai materi belajarnya,

${ }^{23}$ Chairani, L. Menghafal Al-Qur'an Itu Mudah, menjaganya yang Sulit : Dinamika Regulasi Diri Pada Remaja Penghafal Al-Qur'an. Thesis (tidak diterbitkan) Yogyakarta: Pasca Sarjana UGM, 2008.

${ }^{24}$ Bandura, A. Soscial Foundations of Thought and Actions: A Social Cognitive Theory. New Jersey: Prentice Hall. Inc. 1986.

$194 \mid$ JURNAL LISAN AL-HAL 
dan orientasi performansi merupakan upaya pembelajar untuk menyenangkan orang lain atau ingin mengalahkan orang. 25 Hasil penelitian mebuktikan bahwa orientasi tujuan berkorelasi secara positif dengan hasil kerja kognitif dan kinerja individu. ${ }^{26}$ Orientasi tujuan menjadi penting karena tujuan belajar itu sendiri dapat berfungsi sebagai motivasi dalam belajar.

Proses penetapan tujuan belajar didukung oleh kemampuan metakognitif pembelajar. ${ }^{27}$ Faktor yang menentukan tingkat motivasi seseorang adalah efikasi diri terhadap sesuatu mempengaruhi motivasi seseorang untuk melakukan sesuatu. Jika ia merasakan bahwa dirinya mampu meraih tujuan, maka ia akan bekerja lebih keras, dan sebaliknya jika ia memiliki efikasi diri rendah, maka ia tidak akan memiliki motivasi tinggi untuk meraih tujuan. ${ }^{28}$ Dalam menetapkan tujuan belajar, pembelajar dituntut mampu menggerakkan fikiran, perasaan, dan perilaku secara terencana, dan secara siklikal disesuaikan dengan tujuan personal yang akan dicapai. Pembelajar yang memiliki tujuan belajar merupakan individu yang memiliki motivasi, independensi, dan merupakan partisipan yang aktif secara metakognitif dalam belajar dan melibatkan semua faktor individual yang mempengaruhi kinerja belajarnya. Eggen dan Kauchak, mengatakan bahwa regulasi diri pada pelajar adalah proses penggunaan fikiran dan tindakan-tindakan strategis dapat dilakukan pembelajar apabila ia mengetahui tentang tujuan belajar dan persepsi terhadap efikasi dirinya. ${ }^{29}$ Pembelajar memiliki keyakinan akan kemampuan melakukan kontrol, memiliki harga diri, kecenderungan menyelesaikan tugas yang lebih baik, bertanggungjawab, dan berorientasi ke masa depan.

Belajar tidak hanya menjalani sebuah proses yang penuh tugastugas belajar, akan tetapi juga penuh dengan tantangan dan hambatan yang dapat mengganggu terselesaikannya tugas dalam periode waktu yang

${ }^{25}$ Chen, S. S. Self-regulated learning strategies and achievement in an introduction to information systems course. Information Technology, Learning, and Performance Journal, 20,11-22. 2002

${ }^{26}$ Ablard, K.E. \& Lipschultz, R.E. Self regulated learning in high achieving students: Relation to advanced reasoning, achievement goals, and gender. Journal of Educational Psychology, 90, 94-101. 1998.

${ }^{27}$ Montalvo, F.T \& Torres, M.C.G. Self-Regulated learning : Current and future directions. Electronic Journal of Research in Educational Psychology, 2 (1), 1-34. 2004.

${ }^{28}$ Zimmerman, B. J. (2008). Investigatting self-regulation and motivation : Historical background, methodological development, and future prospects, American Educational Journal, 45 (1), hlm. 166-183.

${ }^{29}$ Eggen, P., \& Kauchak, D. Educational psychology: Windows on classrooms $\left(8^{\text {th }} \mathrm{ed}.\right)$. New Jersey: Pearson Education, Inc. 2010, hlm 185-187. 
terbatas. Kondisi ini memungkinkan pembelajar akan meninggalkan tugas-tugas tersebut. Schunk, mengatakan bahwa kuantitas tugas dan tingginya hambatan yang dihadapi oleh pembelajar dapat dihadapi dengan cara pembelajar meregulasi kognisi dan motivasinya. ${ }^{30}$ Bentuk regulasi kognisi disini yaitu pembelajar harus memiliki tujuan, akan berinisiatif mempertahankan atau meningkatkan tekadnya untuk memulai, mengarahkan kinerjanya untuk mencapai tujuan tersebut. Sedangkan regulasi emosi berupa upaya pembelajar mengontrol motivasi untuk tetap persisten, pengelolaan afeksi, lingkungan, dan perilaku.

Bentuk belajar berdasar regulasi diri santri pembelajar yang ditemukan pada penelitian ini, yaitu santri menggunakan berbagai strategi belajar untuk mencapai tujuan belajarnya. Beberapa strategi belajar yang digunakan oleh santri diantaranya, yaitu; memahami konsep pelajaran dengan menggunakan kata-kata sendiri, melakukan resume, membuat skema, mencari bantuan orang dewasa atau teman sebaya yang lebih mampu, dan lebih sering melakukan reviu terhadap belajar dan hasil belajarnya. Slavin, menyatakan bahwa strategi belajar merupakan teknik untuk memecahkan problem, memasukkan dan mempertahankan informasi yang diperoleh, mengontrol peristiwa, mengontrol lingkungan, mengingat, mengelaborasi, mengorganisasi, mengelola waktu, mengelola usaha, mengelola kondisi lingkungan, melakukan strategi kognitif, mengontrol diri, dan mencari bantuan sosial. ${ }^{31}$ Strategi belajar mengoptimalkan kemampuan strategi kognitif seperti mengulang materi pelajaran, melakukan elaborasi, mengorganisasi bahan pelajaran, menghapal atau menggunakan cara-cara tertentu untuk membantu ingatan.

Zimmerman, mengatakan bahwa konsep belajar berdasar regulasi diri secara khusus berhubungan dengan pelajar yang metakognisinya aktif, termotivasi secara intrinsik, dan menggunakan strategi dalam belajar. $^{32}$ Belajar berdasar regulasi diri merupakan kombinasi keterampilan belajar akademik dan pengendalian diri yang membuat pembelajar terasa lebih mudah mengatur cara belajarnya untuk kemudian mentransformasikan kemampuan mentalnya menjadi keterampilan dan

${ }^{30}$ Schunk, Dale. H. Learning theories: an educational perspective ( $5^{\text {th }}$ ed.). New Jersey: Pearson Education, Inc, 2008, hlm. 116-121.

31Slavin, Robert. E. Educational psychology: Theory and practice (9thed.). New Jersey: Pearson. 2009, hlm. 204-206.

32Zimmerman, B. J. Self-regulated learning and academic achievement: An overview. Educational Psychologist, 25, 3-17, 1990.

196 | JURNAL LISAN AL-HAL 
strategi akademik seperti perencanaan atau orientasi tujuan belajar. ${ }^{33}$ Perencanaan diasumsikan terjadi atas dasar sifat tugas dan lingkungan, pengetahuan, tujuan, efikasi diri, keadaan afektif, dan hasil dari kontrol perilaku. ${ }^{34}$ Penggunaan strategi belajar akan meningkatkan kualitas belajar karena pembelajar dapat mentransformasi kemampuan mentalnya ke dalam kemampuan akademik dan dapat belajar melalui pengalaman dan refleksi diri.

Penggunaan strategi belajar berdasar regulasi diri tidak hanya bergantung pada pengetahuan mereka mengenai strategi, tapi juga berdasar pada proses pengambilan keputusan metakognitif dan hasil kinerja mereka. Pada level regulasi diri yang bersifat umum, analisis tugas atau perencanaan adalah proses pengambilan keputusan untuk memilih dan mengubah strategi regulasi diri secara umum. ${ }^{35}$ Pada level regulasi diri yang sifatnya khusus, proses kontrol perilaku nampak dalam aktivitas pembimbingan dan pengarahan atensi, pelaksanaan aktivitas, persistensi, dan pemantauan terhadap respon. ${ }^{36}$ Pengorganisasian, penetapan tujuan dan rencana, evaluasi diri, mencari informasi dan bantuan sosial, memonitor perilaku, mengatur lingkungan fisik, mengulang, mengingat, dan mereviu bahan pelajaran merupakan usaha yang dilakukan pembelajar dalam menjalani aktivitas belajarnya. Semua upaya yang dilakukan pembelajar dilakukan secara persisten sehingga didapat hasil belajar yang optimal.

Karaktristik perilaku dalam belajar berdasar regulasi diri adalah perilaku memilih, mengatur, dan menciptakan lingkungan yang dapat mengoptimalkan belajar dengan menunjukkan tindakan mencari bantuan berupa saran atau informasi. ${ }^{37}$ Saran ataupun informasi salah satunya diperoleh melalui belajar kelompok. Selanjutnya, dikatakan bahwa pembelajar yang dikarakterkan mempunyai motivasi berprestasi, aktif,

${ }^{33}$ Chen, S. S. Self-regulated learning strategies and achievement in an introduction to information systems course. Information Technology, Learning, and Performance Journal, 20,11-22. 2002.

34Zimmerman, B. J. \& Paulsen, A. S. Self monitoring during collegiate studying: An invaluable tool for academic self-regulation. In P.R. Pintrich (Ed.), Understanding selfregulated learning (pp. 13-27). San Francisco, California: Jossey-Bass. 1995.

${ }^{35}$ Slavin, Robert. E. Educational psychology: Theory and practice (9 $\left.{ }^{\text {th }} \mathrm{ed}.\right)$. New Jersey: Pearson. 2009, hlm. 204-206.

${ }^{36}$ Pintrich, P. R. A motivational science perspective on the role of student motivation In learning and teaching contexts. Journal of Educational Psychology, 95(4), 667-686. 2003.

${ }^{37}$ Bandura, A. Soscial Foundations of Thought and Actions: A Social Cognitive Theory. New Jersey: Prentice Hall. Inc. 1986. 
berorientasi pada tugas atau memiliki dasar pengetahuan lebih banyak, akan mencari bantuan ketika ia memerlukannya. Sekalipun demikian, mencari bantuan, tidak selalu murni strategi belajar, karena mencari bantuan pada orang lain dapat juga merepresentasikan interaksi sosial. Oleh karena itu, mungkin saja pelajar yang motif sosialnya tinggi akan banyak menggunakan strategi mencari bantuan dalam belajar.

Belajar berdasar regulasi diri yang ditunjukan oleh santri pembelajar tidak selalu menghasilkan tercapainya orientasi tujuan yang dimiliki oleh setiap sumber data. Salah satu sumber data penelitian (SH) mengalami hambatan-hambatan dalam mencapai kesuksesan belajar untuk meraih prestasi akademik yang tinggi di bangku madrasah. Meskipun ia telah mengupayakan untuk dapat mencapai target yang ia tentukan untuk meraih prestasi akademik yang tinggi di bangku madrasah, akan tetapi ia seringkali mengalami hambatan untuk fokus belajar. Hal ini terjadi karena ketika ia mencoba fokus untuk belajar materi pelajaran madrasah atau sekolah sering kali berbenturan dengan kegiatan kepesantrenan yang sulit ditinggalkan.

Kegagalan dalam memenuhi target seperti yang dilakukan oleh subjek SH ini sejalan dengan penyataan dari Pintrich yang menyebutkan bahwa perspektif regulasi diri dalam belajar mengasumsikan seorang pembelajar memiliki potensi untuk dapat mengontrol dan meregulasi beberapa aspek pada diri mereka seperti kognisi, motivasi, perilaku dan juga beberapa aspek lingkungan mereka. ${ }^{38}$ Perspektif regulasi diri dalam belajar mengakui bahwa ada peran biologis, perkembangan, kontekstual dan kendala perbedaan individu yang dapat menghambat atau mengganggu individu melakukan regulasi. Faktor situasi dan lingkungan yang menjadi pencetus terhadap terjadinya belajar berdasar regulasi diri seperti aktivitas yang padat diberbagai peran, keinginan untuk berhasil dalam pembelajaran, hambatan dalam memenuhi tuntutan belajar, dan dukungan yang diberikan oleh orang terdekat seperti kepala kamar, guru, dan teman.

Berhasil tidaknya seorang pembelajar dalam meraih sebuah kesuksesan atau prestasi ditentukan oleh cara belajarnya, bagaimana ia belajar, dengan siapa belajar dan bagaimana cara belajaranya. Salah satu strategi belajar yang sering digunakan oleh sumber data adalah belajar

${ }^{38}$ Pintrich, P. R. A motivational science perspective on the role of student motivation In learning and teaching contexts. Journal of Educational Psychology, 95(4), 667-686. 2003.

198 JURNAL LISAN AL-HAL 
kelompok adalah belajar bersama dengan satu atau lebih orang lain atau teman sekolah guna penyelesaian masalah atau tugas-tugas belajar untuk meningkatkan prestasi belajarnya. ${ }^{39}$ Dalam pandangan teori konstruktivistik, belajar kelompok memberikan pengalaman-pengalaman baru bagi pembelajar, interaksi yang dibangun dalam kelompok dapat mendorong kerjasama dan setiap individu meberikan kontribusi untuk memotivasi satu sama lain untuk mencapai tujuan bersama. Melalui belajar kelompok pula mereka dapat meningkatkan kemampuan memecahkan masalah dan menggunakan cara berfikir yang kritis sehingga dapat menyelesaikan tugas dengan efektif.

Efektivitas belajar kelompok dipengaruhi oleh faktor seperti; tipe materi pelajaran, taraf kesukaran pelajaran, karakteristik pembelajar, dan jumlah anggota kelompok. Mencari bantuan belajar pada orang lain, awalnya dipandang sebagai suatu ketergantungan, tapi sebenarnya merupakan strategi belajar proaktif yang dapat memfasilitasi prestasi belajar. ${ }^{40}$ Melalui belajar kelompok, pembelajar dapat menumbuhkan kemampuan menjalin komunikasi, bersikap kooperatif, saling support, saling membantu satu sama lain. Melalui diskusi kelompok, para santri pembelajar juga memperoleh dukungan atau sebagai sumber dukungan yang menguntungkan bagi mereka. Menurut Schunk, dukungan sosial adalah pemberian informasi baik secara verbal maupun non verbal, pemberian bantuan tingkah laku atau materi yang didapat dari hubungan sosial. ${ }^{41}$ Dalam hal ini, santri pembelajar yang merasa memperoleh dukungan sosial secara emosional meraka merasa nyaman karena diperhatikan, mendapat saran atau kesan yang menyenangkan pada dirinya.

Belajar berdasar regulasi diri yang dilakukan oleh sumber data adalah regulasi kognitif, metakognitif, motivasi, dan perilaku. Disamping empak aspek tersebut mereka juga melakukan regulasi emosi, yaitu dengan memilih mata pelajaran yang disenangi terlebih dahulu untuk menumbuhkan motivasi belajar terhadap mata pelajaran lain yang kurang disukai. Hal ini dilakukan untuk menjaga emosi tetap stabil diberbagai

${ }^{39}$ Miller, D. C. \& Byrnes, J. P. To Achieve or Not to Achieve: A Self-Regulation Perspective on Adolescent' Academic Decision Making. Journal of Educational Psychology. 93, 677-685. 2001.

${ }^{40}$ Zimmerman, B. J. Investigatting self-regulation and motivation : Historical background, methodological development, and future prospects. American Educational Journal, 45 (1), 166-183. 2008.

41Schunk, Dale. H. Learning theories: an educational perspective ( $5^{\text {th }}$ ed.). New Jersey: Pearson Education, Inc. 2008, hlm. 116-121. 
situasi belajar. Regulasi emosi yang ditemukan dalam penelitian ini diketahui bahwa sumber data memilih dan beradaptasi terhadap suatu strategi agar afeksinya dapat membantu dalam regulasi diri dalam belajarnya, tetapi juga dilakukan pada saat mereka akan memulai suatu kegiatan pembelajaran seperti ketika akan mereview materi pemebelajaran seperti kitan dan buku pelajaran atau mengerjakan tugas. Regulasi emosi yang dilakukan oleh sumber data selaras dengan pendapat Miller \& Byrnes, yang menyatakan bahwa kemampuan individu untuk tidak terpengaruh oleh emosi negatif yang dirasakan sehingga dapat tetap berpikir dan melakukan sesuatu yang baik. ${ }^{42}$ Seluruh sumber data berupaya menemukan cara agar emosi negatif yang dirasakan dapat segera hilang sehingga mereka dapat mnyelesaikan tugas-tugas dengan baik.

Temuan lain pada penelitian ini adalah strategi dalam memecahakan masalah yang dihadapi oleh santri. Salah satu cara yang digunakan santri untuk memecahkan masalahnya dengan cara mencari bantuan (help seeking). Mencari bantuan belajar pada orang lain dengan bertanya kepada guru, orangtua, atau teman ketika menghadapi kesukaran belajar, awalnya dipandang sebagai suatu ketergantungan, tapi sebenarnya merupakan strategi belajar proaktif yang dapat memfasilitasi prestasi belajar. ${ }^{43}$ Mencari bantuan belajar merupakan salah satu cara mengelola sumber daya dalam belajar berupa lingkungan fisik dan sosial berupa usaha mencari bantuan dalam belajar. Mencari bantuan merupakan upaya pembelajar meminta konfirmasi dan pemecahan masalah aktual. Schunk, menyatakan bahwa pembelajar dengan orientasi tujuan yang dimilikinya akan mengarahkan sumber daya yang dimilikinya pada perilaku mencari bantuan. ${ }^{44}$ Hasil penelitian membuktikan bahwa pembelajar yang dikarakterkan mempunyai motivasi berprestasi, aktif, berorientasi pada tugas atau memiliki dasar pengetahuan lebih banyak, akan mencari bantuan ketika ia memerlukannya. ${ }^{45}$ Fokus dari mencari

${ }^{42}$ Miller, D. C. \& Byrnes, J. P. To Achieve or Not to Achieve: A Self-Regulation Perspective on Adolescent' Academic Decision Making. Journal of Educational Psychology. 93, 677-685. 2001.

${ }^{43}$ Alsa, A. Program Belajar, Jenis Kelamin, BelajarBerdasar Regulasi Diri dan Prestasi BelajarMatematika Pada Pembelajar SMA Negeridi Yogyakarta. Disertasi tidak diterbitkan, Yogyakarta, Pasca Sarjana UGM, 2007.

${ }^{44}$ Schunk, Dale. H. Learning theories: an educational perspective (5 ${ }^{\text {th }}$ ed.). New Jersey: Pearson Education, Inc. 2008, hlm. 116-118.

${ }^{45}$ Purdie, N., Hattie, J., \& Douglas, J. Student Conceptions of Learning and Their Use of

$200 \mid$ JURNAL LISAN AL-HAL 
bantuan yang dilakukan sumber data adalah melakukan klarifikasi terhadap substansi materi pembelajaran yang belum dimengerti atau belum dikuasai. Upaya yang dilakukan oleh mereka menjadikannya sebagai pembelajar yang tidak mudah putus asa, selalu terlibat aktif dalam usaha mencari bantuan, dan transformasi informasi untuk pemahaman yang lebih baik. Oleh karena itu, santri pembelajar yang motif sosialnya tinggi akan banyak menggunakan strategi mencari bantuan dalam belajar.

Guna menjaga persistensi belajar berdasar regulasi diri santri, mereka selalu melakukan regulasi motivasi dalam bentuk usaha yang disengaja untuk mengontrol belajarnya. Regulasi motivasi merupakan proses menyangkut fikiran dan tindakan pelajar dan strategi-strategi untuk meregulasi berbagai keyakinan motivasional. ${ }^{46}$ Santri secara sadar dan secara intensional berusaha mempengaruhi motivasinya untuk meraih tujuan tertentu. Inisiatif untuk mempertahankan kemauannya untuk memulai dan mengarahkan kerjanya untuk mencapai tujuan tersebut dengan sengaja. Disamping melakukan regulasi motivasi, sumber data juga melakukan regulasi metakognitif yang merupakan unsur penting dalam belajar berdasar regulasi diri. Regulasi metakognitif berhubungan dengan mekanisme regulasi diri seperti perencanaan, pengecekan, pemantauan, pengujian, perbaikan, dan penilaian yang digunakan pelajar dalam aktivitas belajar. ${ }^{47}$ Regulasi metakognitif meliputi sejumlah subproses yang memfasilitasi aspek kontrol dalam belajar yang meliputi perencanaan, penetapan tujuan, pemantauan arah belajar dan pemahaman belajar, penemuan dan perbaikan kesalahan, serta penemuan cara yang lebih baik lagi dalam memecahkan problem belajar.

\section{Simpulan}

Kesimpulan dari penelitian ini yaitu bahwa santri pembelajar melakukan regulasi diri dalam belajarnya sebagai hasil dari struktur kausalitas interdependen resiprokal triadik dari aspek pribadi, perilaku, dan lingkungan. Belajar berdasar regulasi diri santri pembelajar dapat ditemukan pada regulasi diri intrapersonal (individual) meliputi; regulasi kognitif, strategi belajar metakognitif, regulasi perilaku, dan regulasi

Self-Regulated Learning Strategies: A Cross Cultural Comparison. Journal of Educational Psychology, 88, 87-100. 1996.

${ }^{46}$ Eggen, P., \& Kauchak, D. Educational psychology: Windows on classrooms (8 ${ }^{\text {thed.). }}$ New Jersey: Pearson Education, Inc. 2010, hlm 185-187.

${ }^{47}$ Slavin, Robert. E. Educational psychology: Theory and practice (9 ${ }^{\text {thed.). New }}$ Jersey: Pearson. 2009, hlm. 204-206. 
emosi; dan regulasi diri interpersonal (sosial) seperti mencari bantuan dan diskusi kelompok.

Sebagai bahan pertimbangan, santri yang memiliki peran yang sama dengan sumber data pada penelitian ini dapat mempertimbangkan strategi belajar berdasar regulasi dan mengantisipasi kemungkinankemungkinan situasi yang dapat terjadi dengan mempersiapkan atau merencanakan strategi belajar berdasar regulasi diri dalam hal regulasi kognitif, metakognitif, regulasi motivasi, perilaku, dan regulasi emosi. Guna pengembangan keilmuan, penelitian ini perlu dilakukan peneliatan lanjutan untuk menggali model-model belajar berdasar regulasi pada santri dengan sumber data yang lebih variatif dalam lingkup setting sosial budaya yang berbeda.

\section{DAFTAR PUSTAKA}

Ablard, K.E. \& Lipschultz, R.E. Self regulated learning in high achieving students: Relation to advanced reasoning, achievement goals, and gender. Journal of Educational Psychology, 90, 94-101. 1998.

Alsa, A. Program Belajar, Jenis Kelamin, BelajarBerdasar Regulasi Diri dan Prestasi BelajarMatematika Pada Pelajar SMA Negeridi Yogyakarta. Disertasi tidak diterbitkan, Yogyakarta, Pasca Sarjana UGM, 2007.

Bandura, A. Soscial Foundations of Thought and Actions: A Social Cognitive Theory. New Jersey: Prentice Hall. Inc. 1986.

Chairani, L. Menghafal Al-Qur'an Itu Mudah, menjaganya yang Sulit : Dinamika Regulasi Diri Pada Remaja Penghafal Al-Qur'an. Thesis tidak diterbitkan, Yogyakarta Pasca Sarjana UGM. 2008.

Chen, S. S. Self-regulated learning strategies and achievement in an introduction to information systems course. Information Technology, Learning, and Performance Journal, 20,11-22. 2002.

Eggen, P \& Kauchak, D. Educational psychology: Windows on classrooms

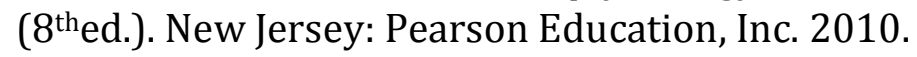

Miller, D. C. \& Byrnes, J. P. To Achieve or Not to Achieve: A Self-Regulation Perspective on Adolescent' Academic Decision Making. Journal of Educational Psychology. 93, 677-685. 2001.

Montalvo, F.T \& Torres, M.C.G. Self-Regulated learning : Current and future directions. Electronic Journal of Research in Educational Psychology, 2 (1), 1-34. 2004.

Papalia, Diane. E., Old, Salle. W, \& Feldman, Ruth. D. Human Development.Terjemahan edisi ke-9: Anwar, K.A. Jakarta: Pernada

$202 \mid$ JURNAL LISAN AL-HAL 
Media Grup. 2008.

Pintrich, P. R. A motivational science perspective on the role of student motivation In learning and teaching contexts. Journal of Educational Psychology, 95(4), 667-686. 2003.

Purdie, N., Hattie, J., \& Douglas, J. Student Conceptions of Learning and Their Use of Self-Regulated Learning Strategies: A Cross Cultural Comparison. Journal of Educational Psychology, 88, 87-100. 1996.

Santrock, Jhon. W. Life-span development (Edisi Kelima). Alih bahasa oleh Juda Damanik dan Achmad Chusairi. Jakkarta: Penerbit Erlangga. 2008.

Schunk, Dale. H. Learning theories: an educational perspective $\left(5^{\text {th }} \mathrm{ed}\right.$.). New Jersey: Pearson Education, Inc. 2008.

Slavin, Robert. E. Educational psychology: Theory and practice ( $9^{\text {th }} \mathrm{ed}$.). New Jersey: Pearson. 2009.

Steffens, K. Self-regulated learning in technology enhanced learning environments: Lessons of a european peer. European Journal of Education, 41 (3/4), 353-379. 2006.

Subandi, M. A. Psikologi Dzikir. Yogyakarta. Pustaka Pelajar. 2009.

Zimmerman, B. J. Self-regulated learning and academic achievement: An overview. Educational Psychologist, 25, 3-17, 1990.

Zimmerman, B. J. Academic studying and the development of personal skill: A self-regulatory perspective. Educational Psychologist, 33, 73-86. 1998.

Zimmerman, B. J. Investigatting self-regulation and motivation : Historical background, methodological development, and future prospects, American Educational Journal, 45 (1), 166-183. 2008.

Zimmerman, B.J. \& Martinez-Pons, M. Pursuing academic self-regulation : a 20-years methodological quest. Dalam Jessie-Ee, Chang,A,.\& Tan, C.S. (Eds), Thinking about thinking : What educators need to know. (hh.3-30) Singapura: McGraw-Hill Education (Asia). 2004.

Zimmerman, B. J. \& Paulsen, A. S. Self monitoring during collegiate studying: An invaluable tool for academic self-regulation. In P.R. Pintrich (Ed.), Understanding self-regulated learning (pp. 13-27). San Francisco, California: Jossey-Bass. 1995. 


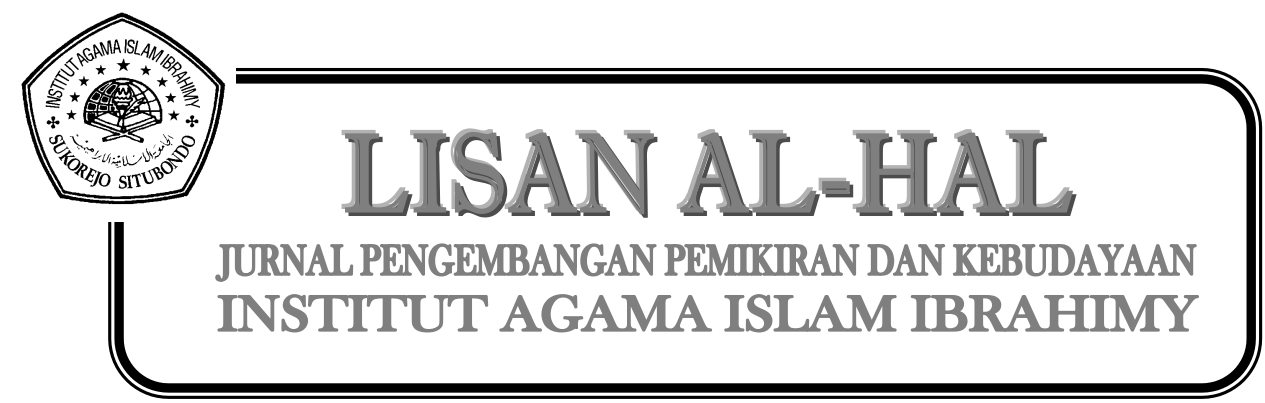

204 JURNAL LISAN AL-HAL 
